LENTERA PENDIDIKAN, EDISI X, NO. 2, DESEMBER 2007 (128-137)

\title{
SINERGI AGAMA DAN SAINS: Suatu Paradigma Menuju Era Globalisasi Pendidikan
}

\author{
Oleh: Muhamad Wayong
}

\begin{abstract}
Modern scientific theory today finds itself quite close to the Qur'an. One reason for this is that science has not been able to produce theories or experiments that fundamentally contradict the Qur'an. Another reason for the harmony between the Qur'an and science is the presence in the Qur'an itself of very clear and positive encouragement to contemplate and investigate the world around us. However, the Qur'an goes beyond simply encouraging all human beings to be aware of the natural world. The non-Muslims in the West have already been advanced in this respect, but...why are Muslims left far behind?
\end{abstract}

KEYWORDS: Agama, sains, pendidikan Islam, globalisasi pendidikan

LEMBAGA Penelitian Nasional Prancis (The Centre of National Research) menyatakan bahwa dunia dewasa ini sedang memasuki perkembangan baru globalisasi, yaitu globalisasi budaya. Globalisasi pertama adalah globalisasi politik yang dimulai dengan terbentuknya Persatuan BangsaBangsa (PBB) pada tahun 1945. Tiga puluh tahun setelah itu, diperkirakan pada pertengahan tahun 1970-an, muncul globalisasi kedua, yaitu globalisasi ekonomi. Ini ditandai dengan lahirnya berbagai kesepakatan seperti APEC, AFTA, dan lain-lain. Tiga puluh tahun berikutnya, sekitar pertengahan tahun 2000-an, dunia mulai memasuki sebuah babak baru globalisasi, globalisasi ketiga, yaitu globalisasi budaya. Hingga tahap ini, globalisasi budaya merupakan yang paling rumit, sedangkan yang paling mudah adalah globalisasi ekonomi, walau globalisasi ini telah memperlebar jurang antara negara-negara utara dan selatan. ${ }^{1}$

Globalisasi budaya menjadi rumit karena di satu sisi ada ambiguitas yang melekat pada globalisasi ini yaitu sangat terbukanya dunia. Namun, di sisi lain ada daya untuk mempertahankan nilai budaya tertentu, karena globalisasi budaya mendorong untuk mengetahui perbedaan satu sama lain. Pertemuan budaya yang kian sering terjadi mengakibatkan penguatan budaya lokal karena setiap bangsa ingin mempertahankan identitas budaya tersendiri (Asumsi ini tidak sejalan dengan tesis Samuel Huntington 
yang menyatakan bahwa masa depan dunia akan diwarnai dengan peran peradaban). ${ }^{2}$

Perhitungan tenggang waktu munculnya setiap globalisasi, yaitu setiap tiga puluh tahunan, memprediksi bahwa tiga puluh tahun setelah globalisasi budaya akan muncul globalisasi baru sekitar tahun 2030-an yang kemungkinan besar adalah globalisasi pendidikan. ${ }^{3}$ Fakta menunjukkan bahwa dewasa ini sudah banyak perguruan tinggi di negara-negara maju yang memiliki cabang di sejumlah negara lain. Contoh, Monah University dari Australia telah memiliki cabang di Singapura, SarawakMalaysia, Hongkong, Cina, dan lain-lain. Tidak menutup kemungkinan perguruan tinggi terkemuka dunia lainnya akan membuka cabang-cabang baru ke seluruh penjuru dunia, termasuk Indonesia.

Kekhawatiran bahwa ketika lembaga pendidikan sekuler mengendalikan dunia pendidikan, maka isu sekulerisme semakin sulit diatasi. Dasar pemikiran ini menjadi tantangan bagi lembaga pendidikan Islam di seluruh dunia. Isu ini menjadi alasan untuk menegaskan perlunya merealisasikan sebuah paradigma pendidikan yang mensinergikan pendidikan agama dan sains untuk menghidupkan intelektualitas di negara-negara mayoritas muslim yang telah lama stagnan.

\section{STAGNASI INTELEKTUALITAS DI DUNIA ISLAM?}

Salah satu cara menjawab asumsi ini adalah dengan menghitung berapa banyak perguruan tinggi bertaraf international yang berada di negara mayoritas Muslim. Di akhir tahun 2006, The Times Higher Education Supplement (THES) menetapkan 200 universitas top dunia. Klasifikasi ini menunjukkan bahwa mutu pendidikan di negara yang mayoritas penduduknya beragama Islam sangat rendah. Di antara 200 perguruan tinggi terkemuka dunia, 54 universitas berada di Amerika Serikat yang berpenduduk sekitar 5 persen penduduk dunia. Sedangkan 46 negara mayoritas Muslim yang berpenduduk sekitar 16 persen penduduk dunia hanya menempatkan 2 universitasnya dalam daftar 200 perguruan tinggi tersebut. Dua perguruan tinggi itu adalah Universitas Kebangsaan dan Universitas Malaya di Malaysia. Tanpa meremehkan peringkat keduanya, Universitas Kebangsaan berada pada urutan 185 dan Universitas Malaya berada pada level 192.4

Proses penetapan ranking ini dilakukan oleh the THES dengan mengevaluasi 1000 universitas terkemuka dari seluruh penjuru dunia dengan menggunakan lima indikator. Salah satu indikator yang digunakan adalah input dari 3700 akademisi yang aktif di bidang riset dari berbagai disiplin di seluruh dunia. Para akademisi tersebut diminta untuk menetap- 
kan 30 research universities terkemuka serta menghitung hasil riset yang telah dipublikasikan di masing-masing lembaga itu. Indikator lain yang digunakan adalah jumlah mahasiswa asing yang belajar di perguruan tinggi tersebut, rasio antara dosen dan mahasiswa, serta penilaian perusahaan terkemuka dunia terhadap kualitas alumni perguruan tinggi yang dipekerjakan. ${ }^{5}$

Kelemahan dunia Islam terletak pada bidang sains. Walaupun ada beberapa reseach centres yang maju di beberapa negara mayoritas Muslim, diakui bahwa produktivitas riset di kawasan tersebut tergolong sangat minim. Dengan menggunakan data dari the Science Citation Index yang dibuat oleh the Institute for Scientific Information, Mohamad Anwar dan Abu Baker dari the International Islamic University, Malaysia, menunjukkan bahwa kontribusi total dari 46 negara mayoritas Muslim di seluruh dunia pada bidang sains antara tahun 1990 dan 1994 hanya 1,17 persen dari total international output. Output riset ini sangat minim dibanding India 1,66 persen dan Spanyol 1,48 persen. Studi ini juga menunjukkan bahwa output riset di bidang sains dari 20 negara-negara Arab hanya 0,55 persen dibanding 0,89 persen dari negara Israel saja yang sangat kecil. Walaupun data ini menunjukkan kondisi lebih 10 tahun lalu, setidaknya telah memberikan gambaran betapa minimnya produktivitas riset di negara-negara mayoritas Muslim. Stagnasi intelektualitas di negara-negara Islam, khususnya negara-negara Arab diperkuat oleh temuan the United Nation Development Fund (UNDF) bahwa dalam kurun waktu 1000 tahun penerjemahan dan penulisan buku di 20 negara-negara Arab ternyata hanya sebanding dengan penerjemahan dan penulisan buku di Spanyol dalam kurun waktu setahun saja. ${ }^{6}$

Seorang ilmuan Muslim terkemuka, Abdus Salam, menambahkan bahwa berdasarkan hasil survei yang ia lakukan dalam kurun 20 tahun terakhir, negara-negara mayoritas Islam ternyata yang paling terbelakang dalam bidang sains dan teknologi. ${ }^{7}$ Keterbelakangan ini menjadi ancaman serius bagi dunia Islam mengingat kemajuan suatu bangsa dewasa ini sangat tergantung pada sains dan teknologinya. Dalam era revolusi industri ketiga, negara-negara maju bersaing di bidang brain industry untuk meraih kemajuan ekonomi. Bagi dunia Islam yang stagnan di bidang ini, konsekuensinya tercermin pada performance ekonominya, dan ini akan menjadi beban yang berat untuk generasi berikutnya. Beberapa negara seperti Korea Selatan, ${ }^{8}$ Singapura, Taiwan, Cina, dan India telah mengeluarkan dana yang besar dalam pengembangan sains dan teknologi dan terbukti negara-negara tersebut dapat leading pada bidang ekonomi di kawasan Asia, bahkan Cina dan India diprediksi akan menjadi negara 
raksasa di bidang ekonomi ${ }^{9}$ menggeser posisi Amerika Serikat dan Jepang pada tahun 2030.

Beberapa faktor dapat menjadi penyebab kelemahan dunia Islam di bidang sains dan teknologi. Pertama, minimnya dana yang dialokasikan pada bidang ini. Jika dirata-ratakan, dana yang dialokasikan hanya sekitar 0,45 persen dari Gross Domestic Product [GDP] dibanding 2,3 persen di negara-negara maju. ${ }^{10}$ Kedua, kolonialisme yang dirasakan oleh sebagian besar negara Islam dalam kurun waktu yang cukup lama. Negara-negara mayoritas Muslim telah dieksploitasi baik ras maupun ekonomi sehingga pembangunan menjadi stagnan.

Terlepas dari dua alasan tersebut di atas, kemunduran dunia Islam di bidang sains dan teknologi terutama disebabkan oleh budaya dan praktek politiknya. Saudi Arabia, sebagai contoh, lebih memprioritaskan pengembangan aliran Wahabiyah ketimbang berinvestasi pada bidng sains dan teknologi. ${ }^{11}$ Dengan alasan dana, sulit dijastifikasi ketidakhadiran universitas terkemuka dunia di Saudi Arabia, juga Kuwait, yang berpenghasilan di atas \$US 500 juta per hari dari expor minyak. Kasus serupa, Indonesia sibuk melakukan reformasi di bidang politik, ekonomi, dan hukum, meskipun tak kunjung sampai pada substansinya. Dalam proses reformasi yang sedang berlangsung ini, ada gejala ke arah dilupakannya sektor pendidikan. Hal ini sungguh amat berbahaya karena konsekuensinya di masa mendatang harus dipikul oleh seluruh komponen bangsa berupa keterbelakangan kolektif dalam wacana kehidupan globalisasi budaya dan globalisasi pendidikan.

Fakta bahwa bangsa Indonesia enggan berinvestasi di bidang pendidikan. Porsi Gross Domestic Product (GDP) yang dialokasikan pada bidang pendidikan hanya rata-rata $1 \%$, bahkan pada era Megawati hanya $0,9 \%$. Porsi ini sangat minim dibanding rata-rata 2-3\% untuk kawasan ASEAN.12 Kebijakan politik Malaysia yang berinvestasi besar-besaran di bidang pendidikan (terutama pada bidang Sains) patut diteladani oleh negara-negara mayoritas Muslim lainnya. Porsi dana pendidikan yang rata-rata diatas 3\%, bahkan $8 \%$ dari GDP pada tahun 2005, telah menjadikan Malaysia satu-satunya negara mayoritas Muslim yang menempatkan dua universitasnya dalam 200 universitas terbaik dunia. Malaysia telah mengembangkan pendidikan yang relevan dengan tuntutan globalisasi: leading di bidang sains, tetapi tidak mengabaikan pendidikan religius.

\section{DARI PARADIGMA LAMA KE PARADIGMA BARU}

Karakteristik perkembangan masyarakat pada era globalisasi budaya di masa yang akan datang diprediksi tidak akan linier lagi dan penuh 
dengan diskontinuitas. ${ }^{13}$ Oleh karena itu, dunia Islam perlu meninggalkan paradigma pendidikan lama yang telah mengabaikan sains dan teknologi agar pada akhirnya mampu membangun masa depan secara bersama demi kemaslahatan umat Islam. Dalam kehidupan globalisasi budaya, batasbatas negara secara fisik-geografis menjadi tidak penting lagi. Justru faktor yang paling penting adalah dikuasainya teknologi informasi. Di satu sisi, dengan adanya penemuan-penemuan baru dalam bidang teknologi informasi, kekuasaan suatu negara dalam arti teritorial menjadi semakin kabur. Di sisi lain, dengan teknologi informasi, umat Islam dapat membelajarkan diri dalam suatu proses pendidikan yang bersifat maya (virtual). Hal ini membawa implikasi bahwa sistem pendidikan harus mampu mempersiapkan umat Islam menjadi komunitas yang benar-benar terberdayakan dalam menghadapi kehidupan global yang semakin lama semakin menggantungkan diri pada teknologi informasi.

Salah satu ciri masyarakat yang terberdayakan oleh sistem pendidikan ialah dimilikinya unggulan komparatif dan unggulan kompetitif ${ }^{14}$ dalam skala global. Untuk menciptakan unggulan-unggulan tersebut, umat Islam memerlukan inovasi yang pesat dalam berbagai bidang pendidikan. Bukan zamannya lagi umat Islam pada umumnya, dan bangsa Indonesia pada khususnya, mengandalkan murahnya tenaga kerja untuk mendukung konsep unggulan kompetitif, tetapi skil individu yang dapat berkompetisi secara global. ${ }^{15}$ Bukan zamannya lagi umat Islam hanya mampu berbicara tentang ayat-ayat qauliyah seperti apa yang tersurat dalam kitab sucinya, tetapi harus pula mendalami ayat-ayat kauniyah yang terbentang di alam semesta ini melalui kegiatan-kegiatan penelitian. Dengan bekal pendidikan religi yang bersumber dari revealed knowledge ${ }^{16}$ semata, umat Islam akan lumpuh dalam menghadapi persaingan global; dengan bekal sains dan teknologi yang bersumber dari acquired knowledge ${ }^{17}$ semata, umat Islam akan kehilangan kontrol dalam mengimplementasikan sains dan teknologi tersebut. Dengan demikian, penyajian antara revealed knowledge dan acquired knowledge secara totalitas ${ }^{18}$ sebagaimana yang tersirat pada beberapa ayat dalam Alquran merupakan hal yang tidak boleh ditunda lagi.

Dalam konteks lokal, transformasi dari IAIN yang hanya menitikberatkan "revealed knowledge" ke UIN yang memadukan antara revealed knowledge dan acquired knowledge merupakan langkah awal dalam mengatasi problematika globalisasi yang dihadapi umat Islam dewasa ini. Paradigma lama (IAIN) mungkin telah mengantar para alumninya menjadi insan yang memahami ajaran agama Islam secara tekstual. Mereka meraih kesalehan religius dalam arti disiplin dalam menjalankan ibadah, tetapi tidak dapat membentuk kesalehan sosial; rajin beribadah, tetapi tidak peka 
terhadap privacy orang lain; rajin beribadah, tetapi gugup dalam berteknologi dan tidak memiliki kemampuan memakmurkan bumi ini sebagai khalifah Allah.

UIN yang mensinergikan antara agama dan sains ${ }^{19}$, antara revealed knowledge dan acquired knowledge, membuka harapan baru khususnya dalam menghadapi persaingan global. Posisi umat Islam sebagai konsumen teknologi diharapkan dapat berubah menjadi produsen teknologi modern secara perlahan-lahan. Sinergi agama dan sains juga akan menjadi identitas dan memberikan nilai tambah kepada Universitas Islam di era globalisasi pendidikan yang diperkirakan akan terjadi sekitar 30 tahun mendatang. Diprediksi bahwa lembaga pendidikan sekuler akan tetap leading pada bidang sains, tetapi krisis dalam konteks kesalehan teknologi. ${ }^{20}$ Pada posisi ini universitas Islam yang mensinergikan antara agama dan sains akan memiliki daya kompetisi yang tinggi. Di era globalisasi pendidikan diasumsikan bahwa perguruan tinggi sekuler yang maju di negara-negara Barat seperti Harvard, Columbia, Cambridge, Oxford University dan lain-lain, akan menjamur cabang-cabangnya di seluruh penjuru dunia. Walaupun begitu, perguruan tinggi Islam yang mensinergikan agama dan sains akan menjadi alternatif utama, terutama ketika lembaga pendidikan pada era tersebut secara global mencari sebuah pendekatan baru dalam pengembangan sains dan teknologi yang lebih konstruktif.

Fakta menunjukkan bahwa semakin maju sains dan teknologi semakin relevan dengan ayat-ayat sains dalam Alquran. Dengan demikian, Alquran harus menjadi inspirasi sekaligus menjadi pedoman moral dalam pengembangan segala bentuk acquired knowledge yang dikembangkan melalui kegiatan penelitian ilmiah.

\section{SAINS DALAM ALQURAN}

Alquran terdiri dari 6666 ayat dan menyentuh seluruh aspek kehidupan manusia. Dari sejumlah ayat tersebut sekitat 1000 di antaranya yang berkaitan dengan sains. Ayat-ayat tentang sains tersebut semuanya tidak bertentangan dengan penemuan-penemuan sains modern seperti dalam bidang Astronomi, Geologi, Biologi, Archaeologi dan lain-lain. Pernyataan-pernyataan dalam Alquran yang dapat dibandingkan dengan penemuan sains modern sangat banyak, tetapi hanya sebagian kecil yang akan dipaparkan pada tulisan ini.

Awal kejadian alam semesta ini telah digambarkan di dalam Alquran. Tanpa merujuk kepada Alquran, para ilmuan Barat berasumsi bahwa sekitar 15 milyar tahun yang lalu alam ini tercipta melalui ledakan 
yang sangat dahsyat dari sebuah benda yang sangat padat. Para astronom dapat melakukan penelitian yang akurat mengenai awal kejadian alam ini hanya setelah dikembangkannya radio telescope pada tahun 1937. Dan mereka menyimpulkan bahwa asumsi tersebut di atas benar. Kesimpulan para astronom sejalan dengan Q.S. al-Anbiyā (21): 30 sebagai berikut:

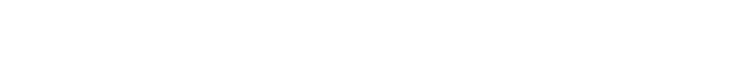

Dan apakah orang-orang yang kafir tidak mengetahui bahwasanya langit dan bumi itu keduanya dahulu adalah suatu yang padu, kemudian Kami pisahkan antara keduanya.

Sinergi ayat-ayat sains dengan penemuan sains modern dapat juga dilihat pada ragam pendapat mengenai apakah bumi itu statis atau tidak. Pada awalnya manusia mengira bahwa bumi ini statis. Pada tahun 1925, Edwin Hubble (Hubble Telescop diberi nama berdasarkan namanya) mengungkapkan hasil penelitiannya bahwa alam ini melebar. Stephen Hawking (penulis buku A Brief History of Time) juga menyimpulkan bahwa: "The universe is not static, as had previously been thought, it is expanding". Artinya, awalnya manusia berpikir bahwa alam ini statis, tetapi kenyataannya dinamis atau meluas. Lebih 1400 tahun yang lalu Allah telah mewahyukannya dalam Surah al-Dzāriyat ayat 47, yang artinya: Dan langit itu kami bangun dengan kekuasaan Kami dan sesungguhnya Kami benar-benar meluaskannya.

Mengenai keberadaan orbit mata hari, nenek moyang kita mengira bahwa mata hari itu berputar mengelilingi bumi. Pada tahun 1512 Nicholas Copernicus memperagakan teorinya mengenai peredaran planet yang disebut Heliocentric Theory. Teori ini menempatkan matahari pada posisi tengah pada sistem tata surya. Matahari itu tidak bergerak, tetapi semua planet yang lain pada tata surya itu bergerak mengelilinginya. Sains modern telah membantah teori Heliocentric ini dengan kesimpulan bahwa matahari juga beredar seiring dengan planet lain pada tata surya. Fenomena ini telah digambarkan oleh Allah dengan firmannya pada Q.S. al-Anbiyā (21): 33, yang artinya: Dan Dialah yang telah menciptakan malam dan siang, matahari dan bulan. Masing-masing dari keduanya itu beredar di dalam garis edarnya.

Alquran juga telah menginformasikan bahwa manusia dapat menaklukkan angkasa. Eksplorasi manusia ke luar angkasa diawali dengan diorbitkannya satelit Rusia yaitu Sputnik I pada Oktober 1957. Lalu disusul dengan peluncuran manusia ke angkasa (Edwin Eldring dan Neil Armstrong) dan mereka sukses mendarat di bulan pada Juli 1967. Sejak itu, mimpi manusia menjelajahi angkasa menjadi kenyataan. Lebih 1400 tahun 
yang lalu Alquran dengan jelas memprediksikan kemajuan dan kemampuan manusia untuk menembus angkasa. Hal ini sejalan dengan firman Allah dalam Q.S. al-Rahman (55): 33, yang artinya: Hai jamaah jin dan manusia, jika kamu sanggup menembus penjuru langit dan bumi, maka lintasilah, kamu tidak dapat menembusnya melainkan dengan kekuatan.

Mengenai perlindungan atmosfir, Allah swt. telah mewahyukannya dalam Alquran. Para ilmuan menemukan bahwa bumi ini secara konstan dibombardir oleh meteoroid yang mengdisintegrasikan atmospir dengan sinar beracun dari matahari. Radiasi ultraviolet ini diisap oleh lapisan ozon yang berada pada posisi paling luar atmosfir. Dengan demikian, atmosfir bersama dengan lapisan ozon berfungsi sebagai pelindung dari radiasi ultraviolet, yang tentunya kehidupan manusia di bumi ini menjadi tidak mungkin tanpa proteksi tersebut. Mendahului penemuan para saintis, Alquran telah menggambarkannya pada Q.S. al-Anbiyā (21): 32, yang artinya: Dan Kami menjadikan langit itu sebagai atap pelindung, sedangkan mereka berpaling dari segala tanda-tanda kekuasaan Allah yang terdapat padanya.

Konsep determinasi jender ditemukan pula dalam Alquran. Para ahli genetika sependapat bahwa sperma adalah faktor yang menentukan jenis kelamin, laki-laki atau perempuan pada embrio. Determinasi sperma lakilaki tersebut berdasarkan fakta bahwa sperma memiliki kromosom $\mathrm{X}$ dan $\mathrm{Y}$, sedangkan ovum perempuan hanya memiliki kromosom X. Dalam Q.S. al-Qiyāmah (75): 36-39 dijelaskan bahwa sperma laki-lakilah penentu jenis kelamin. Allah berfirman yang artinya: Apakah manusia mengira bahwa ia akan dibiarkan begitu saja tanpa pertanggungjawaban? Bukankah dia dulu setetes mani yang ditumpahkan ke dalam rahim, kemudian mani itu menjadi segumpal darah, lalu Allah menciptakannya, dan menyempurnakannya, lalu Allah menjadikan dari padanya dua jenis kelamin, laki-laki dan perempuan.

Terakhir, adalah konsep bahwa ciptaan Allah berpasang-pasangan. Pada mulanya manusia berpikir bahwa jenis kelamin itu hanya terdapat pada hewan: laki-laki dan perempuan atau jantan dan betina. Para ahli kemudian menemukan bahwa fenomena ini juga terdapat pada flora dan ciptaan lainnya. Para ilmuan telah menemukan bahwa pasangan itu juga terdapat pada electricity yaitu positive and negative. Pada bidang magnetism ada kutub utara dan kutub selatan (tidak ada kutub barat dan timur). Pada bidang atom ada pasangan electron and proton. Bahkan bakteri mungkin ada yang positif dan negatif. Fenomena ini digambarkan di dalam Q.S. Yāsīn (36): 36, yang artinya: Maha suci Allah yang telah menciptakan pasanganpasangan semuanya, baik dari apa yang ditumbuhkan oleh bumi dan dari diri mereka maupun dari apa yang mereka tidak ketahui. Diasumsikan bahwa ilmu pengetahuan di masa yang akan datang akan menemukan lagi banyak pasangan yang belum terjangkau dengan sains sekarang. 


\section{PENUTUP}

Kehadiran globalisasi secara periodikal memberikan pengaruh tersendiri kepada lembaga pendidikan Islam. Walaupun kenyataan menunjukkan bahwa globalisasi itu bukan semata-mata pengaruh Barat ke Timur, tetapi juga pengaruh Timur ke Barat, wilayah Timur dimana mayoritas Muslim berdomisili merupakan korban terbesar globalisasi. Dalam dunia pendidikan, lembaga pendidikan di dunia Islam terbukti sangat statis dan tidak berdaya dalam menghadapi kompetisi global. Keterbelakangan ini dipicu dua faktor utama, yaitu paradigma pendidikan yang diterapkan selama ini sangat tradisional serta political will berinvestasi pada dunia pendidikan, terutama pada bidang sains, sangat rendah.

Sinergi agama dan sains pada lembaga pendidikan Islam yang didukung oleh political will yang kuat merupakan salah satu langkah mengurangi resiko globalisasi, terutama globalisasi pendidikan yang pengaruhnya diperkirakan sekitar tahun 2030-an. Paradigma pendidikan yang mensinergikan agama dan sains akan membuat perguruan tinggi Islam, seperti UIN dan International Islamic University di beberapa negara Muslim, resist terhadap pengaruh globalisasi karena pola ini dapat mengurangi ketergantungan dunia Islam terhadap negara yang lebih maju pada bidang sains. Dengan paradigma ini, lembaga pendidikan Islam dapat mengembangkan teknologi tersendiri yang menfasilitasi, bukan ancaman terhadap, kehidupan manusia, karena Alquran akan selalu menjadi pedoman moral dalam penerapan teknologi tersebut.

\section{CATATAN AKHIR:}

1. Lihat Kompas edisi 14, November 2004.

2. Thesis Samuel Huntington disandarkan pada fakta globalisasi sebelumnya bahwa dengan kecepatan informasi dan komunikasi, globalisasi politik dan ekonomi hanya membuat dekatnya jarak teritorial.

3. Tidak menutup kemungkinan di satu saat akan terjadi globalisasi agama atau keyakinan.

4. Lihat Riaz Hassan, "Iislamic Thought in Limbo", The Australian, 19th Edition, December 2006, h. 3-4.

5. Lihat Riaz Hassan, "Iislamic Thought in Limbo", The Australian, 19th Edition, December 2006, h. 3-4.

6. Lihat Riaz Hassan, "Iislamic Thought in Limbo", The Australian, 19th Edition, December 2006, h. 3-4.

7. A. Salam, "Against the Odds", Star Weekend Magazine, Volume 5, February 3, 2006, h. 1-3.

8. United Nations, "Women in the Republic of Korea: A Country Profile, Economic and Social Commission for Asia and the Pacific", Statistical Profile, No. 16, 2001. 
9. United Nations, "Women in India: A Country Profile, Economic and Social Commission for Asia and the Pacific", Statistical Profiles, No. 12, 1997.

10. UNDP, 'Human Development Report 2006', h. 1, viewed 19 February 2007, <http://hdr.undp.org/hdr2006/statistics/indicators/229.html>

11. Lihat Riaz Hassan, "Iislamic Thought in Limbo", The Australian, 19th Edition, December 2006, h. 3-4.

12. UNDP, "Towards a New Consensus: Democracy and Human Development in Indonesia", Indonesia Human Development Report 2001, BPS, BAPPENAS, UNDP, October 2001, h. 1-156.

13. O. Purbo, "Getting Connected: The Struggle to Get Indonesia Online", Inside Indonesia, October-December 2002.

14. Lihat Mansyur Ramly, For Vive Governor: Meneguhkan pendidikan sebagai Lokomotif Pembangunan di Sulawesi Selatan, Jakarta: Teraju, 1997, h. 190-195.

15. Lihat Kompas edisi 14, November 2004.

16. Yang dimaksud dengan revealed knowledge adalah ilmu yang bersumber dari Wahyu, yang tersurat dalam Alquran.

17. Acquired knowledge adalah ilmu yang diperoleh dengan usaha manusia melalui kegiatan penelitian.

18. Model ini telah diprakarsai oleh The League of Islamic Universities lebih 20 tahun yang lalu dengan mengembangkan beberapa International Islamic University seperti yang ada di Malaysia, Pakistan, dan Saudi Arabiyah.

19. Lihat Universitas Islam Negeri (UIN): <http://www.iainmakassar.ac.id>.

20. Lihat contoh Amerika. Mereka telah mengembangkan teknologi nuklir yang sangat destruktif terhadap kehidupan manusia.

\section{DAFTAR PUSTAKA:}

Departemen Agama R.I., Alquran dan Terjemahnya, Semarang: CV Toha Putra, 1989. Kompas edisi 14, November 2004.

Purbo, O., "Getting Connected: The Struggle to Get Indonesia Online", Inside Indonesia, October-December 2002.

Ramly, Mansyur, For Vive Governor: Meneguhkan pendidikan sebagai Lokomotif Pembangunan di Sulawesi Selatan, Jakarta: Teraju, 1997, h. 190-195.

Riaz Hassan, "Iislamic Thought in Limbo", The Australian, 19th Edition, December 2006.

Salam, A., "Against the Odds", Star Weekend Magazine, Volume 5, February 3, 2006.

UNDP, 'Human Development Report 2006', h. 1, viewed 19 February 2007, <http://hdr.undp.org/hdr2006/statistics/indicators/229.html>

UNDP, "Towards a New Consensus: Democracy and Human Development in Indonesia", Indonesia Human Development Report 2001, BPS, BAPPENAS, UNDP, October 2001.

United Nations, "Women in India: A Country Profile, Economic and Social Commission for Asia and the Pacific", Statistical Profiles, No. 12, 1997.

United Nations, "Women in the Republic of Korea: A Country Profile, Economic \& Social Commission for Asia and the Pacific", Statistical Profile, No. 16, 2001.

Universitas Islam Negeri (UIN) website: <http://www.iainmakassar.ac.id>. 